\title{
Unlocking India's potentials in Far East Asian Region: Rethinking Indo- Mongolia ties in the present context
}

\author{
Subhash Kumar ${ }^{1}$, Souvik Chatterjee ${ }^{2 *}$ \\ 1,2Department of Politics and International Relations, Central University of Jharkhand, India \\ *Corresponding Author E-mail: chatterjeesouvik101@gmail.com
}

\begin{abstract}
The Far East refers to the geographical, economic, and cultural regions of Eastern Russia, East Asia, and Southeast Asia. Because it is so geopolitically and culturally diverse, the part is important because of its geostrategic importance, energy resources, and business opportunities. This study will focus on unlocking India's potential in Northeast Asia and Mongolia's important role in India's engagement in the region Despite India's age-old historical, cultural, and religious links with Northeast Asia and Mongolia, India's role remains marginal. With China's increasing presence and dominance in Northeast Asia, India, under the purview of Act East and Connect Central Policy, emphasizes strategic and economic relations with China's closest neighbors such as Mongolia, Japan, etc. Using qualitative research methods Mile and Huberman analysis technique, this research will reveal India's potential in Northeast Asia and Mongolia's important role in terms of India's involvement in the region. As a result, Mongolian foreign policymakers were enticed by India's active engagement in the non-aligned movement, reputation as the world's greatest democracy, and non-interventionist ethos.
\end{abstract}

Keywords: Far East, North East Asia, Act East, Connect Central Asia, Mongolia, Third Neighbors Policy.

\begin{abstract}
Abstrak
Timur Jauh mengacu pada wilayah geografis, ekonomi, dan budaya Rusia Timur, Asia Timur, dan Asia Tenggara. Karena sangat beragam secara geopolitik dan budaya, kawasan ini menjadi penting karena kepentingan geo-strategisnya, sumber daya energi, dan peluang bisnisnya. Studi ini akan berfokus pada membuka potensi India di Asia Timur Laut dan peran penting Mongolia dalam hal keterlibatan India di wilayah tersebut. Terlepas dari hubungan sejarah, budaya dan agama India yang sudah tua dengan Asia Timur Laut dan khususnya dengan Mongolia, peran India tetap marjinal. Dengan kehadiran dan dominasi China yang semakin meningkat di Asia Timur Laut, India di bawah lingkup Act East and Connect Central Policy menekankan pada hubungan strategis dan ekonomi dengan tetangga terdekat China seperti Mongolia, Jepang, dll. Menggunakan metode penelitian kualitatif Teknik analisis mile and Huberman, penelitian ini akan mencoba untuk mengungkap potensi India di Asia Timur Laut dan peran penting Mongolia dalam hal keterlibatan India di wilayah tersebut. Akibatnya, para pembuat kebijakan luar negeri Mongolia terpikat oleh keterlibatan aktif India dalam gerakan non-blok, reputasi sebagai negara demokrasi terbesar di dunia, dan etos non-intervensi.
\end{abstract}

Kata Kunci: Timur Jauh, Asia Timur Laut, Bertindak Timur, Hubungkan Asia Tengah, Mongolia, Kebijakan Tetangga Ketiga.

\section{INTRODUCTION}

The Far East refers to the geographical, economic, and cultural areas of Eastern Russia, East Asia, and Southeast Asia. Being so diverse geopolitically and culturally, this region is getting significance due to its geostrategic importance, energy resources, and business opportunities (Warsah et al., 2019). This region comprises China, Hong Kong, Macau, Japan, North Korea, South Korea, Mongolia, Siberia, Taiwan, Brunei, Cambodia, East Timor, Malaysia, Laos, Indonesia, Myanmar, Singapore, Philippines, Thailand, and

\author{
* Copyright (c) 2021 Subhash Kumar and Souvik Chatterjee \\ This work is licensed under a Creative Commons Attribution-ShareAlike 4.0 International License
}

Received: March 22, 2021; In Revised : Juny 30, 2021; Accepted : July 15, 2021 
Khazanah Sosial, Vol. 3 No. 3: 138-146

Unlocking India's potentials in Far East Asian Region: Rethinking Indo-Mongolia ties in the present context

Subhash Kumar and Souvik Chatterjee

Vietnam. Under the purview of Act East and Connect Central Policy, India is emphasizing strategic and economic relations with China's immediate neighbors such as Mongolia, Japan (Tsokhas, 2013). With these paradigm shifts in Indian foreign policy discourse in mind, this study will try to uncover India's potentials in North-East Asia and the important role of Mongolia in terms of India's engagement in the region.

Following its democratization in the 1990s, the People's Republic of Mongolia, one of Asia's oldest nations, has been determined to change itself from a landlocked to a land-linked cosmopolitan state. (Huang et al., 2013). Mongolia is one of the world's least densely inhabited countries, with a rich historical past and great statehood and foreign ties. Because it is a landlocked country, it is completely surrounded by Russia and China. From the eastern edge of Asia to the furthest reaches of central Europe and from sections of southern Indonesia to Siberia's frigid tundra, his kingdom spanned the globe. (Mote, 2018). This empire is the largest in the world's history. The nation went through several periods of transformation in the centuries following the Mongol empire's peak. For over two centuries after the demise of the Mongol Empire in the 14th century, Mongolian history was devoid of noteworthy occurrences. (Prawdin, 2017).

In contrast to the warring hordes that had controlled the region in earlier centuries, nomadic herders' rhythmic lifestyle defined the pace of existence (D'Evelyn, 2013). Then, beginning in the 17th century, a long period of Chinese influence and occupation began, igniting a rivalry between the two countries that continues to this day. Mongolia did not obtain complete independence from China until the early 1900s, but this independence was swiftly eroded when Russian/Soviet maneuvering began. Mongolia gained independence in 1921, becoming the world's second communist state after the Soviet Union. From 1921 to 1991, Mongolia remained under Soviet influence or, more precisely, under "Soviet control," even though it was never formally a part of the former Soviet Union. However, following the disintegration of the Soviet Union in 1991, Mongolians wasted little time asserting their independence once more (Prawdin, 2017). Mongolia is now a democratic republic with a free-market economy, having accomplished a remarkable transition from its Soviet communist system to a democratic nation with a bold and bright future. As a result of the disintegration of the Soviet Union, Following the complete cessation of essential Soviet economic assistance, Mongolian leaders shifted their attention to the international community, broadening their hunt for multilateral partners and donors to replace the old patron. As part of its foreign policy, the country Mongolia's Third Neighbor strategy has been an attempt by the Mongolian people to counterbalance the influence of their two massive neighbors, the People's Republic of China and the Russian Federation (X. Zhang \& Zhang, 2017). According to the six directions outlined in the Foreign policy framework, Mongolia viewed the West and East countries as key third neighbor partners. Aside from the two neighbors, the United States, Japan, and Germany were considered high-priority nations. Mongolia wanted good relations with countries as different as India, Japan, and the Republic of Korea at the same time. Thailand, Singapore, Turkey, Denmark, the Netherlands, Finland, Austria, Sweden, and Switzerland are just a few countries represented (Ganbat, 2012).

In the case of India's relations with Mongolia have remained warm since time immemorial. Even though the political and diplomatic dialogues between them are not at par, their relationship's cultural aspects are highly emphasized for ages (Chandramohan, 2015; Soni, 2016). Tibetan Buddhism, the most dominant religion in Mongolia, undoubtedly makes cultural linkages between the two. Buddhism penetrated Mongolia in roughly the 5th century A.D. Subsequently, several Indian missionaries visited the country that consolidated further cultural dialogues between the two civilizations (J. Zhang, 2012). Similarly, there is also a linguistic affinity between the two. Several words that are used frequently 
Khazanah Sosial, Vol. 3 No. 3: 138-146

Unlocking India's potentials in Far East Asian Region: Rethinking Indo-Mongolia ties in the present context

Subhash Kumar and Souvik Chatterjee

in the Mongolian language are derived from Sanskrit directly like Sansar, Avyas, etc. not only there is a linguistic or religious connection between the two nations there so many spheres starting from wresting to attire there is a great degree of resemblance between the two (Nyamdavaa, 2003). Thus Mongol-Indian relations have been ancient and deeply rooted, and due to various linkages, Prof. Oidov Nyamdeva dubbed them as 'spiritual neighbors' (Nyamdavaa, 2003). Today Mongolia, especially after its democratic transition in the 1990s, tries to increase its area of interest beyond Russia and China while engaging with the major powers in the world. At the same time Mongolia is keen to overcome its compulsion of physical distance by taking active participation in various international and regional groupings like United Nations, Asian Development Bank, Shanghai cooperation etc. So in this changing pattern of world economy Mongolia will definitely act as a pivot and catalyst for Northeast Asia's regional co-operation due to Mongolia's geographical, strategic position.

For this reason, research on the role of India in unleashing India's potential in the Far East is a must because this relationship will have a good impact on both countries. Besides that, there has been no specific research that examines this theme, so there are still many shortcomings that still need to be explained through research. This will be useful for the governments of India and Mongolia as reference material in future policy planning.

\section{RESEARCH METHOD}

Despite India's old age historical, cultural, and religious linkages with the region, India's role remained marginal. Let's make a comparative study between China and India two most dominant nation in the area. We can easily observe China's ever reaching presence and dominance in North-East Asia. While China can transcend its interests beyond its immediate neighbors, India's ability to increase its presence in Far East Asia remained inadequate. But at the same time, Indian policymakers being conscious about Chinese strategic encircling policy, are trying hard to counter this by delving into close strategic and enhancing economic relations with China's immediate neighbors such as Mongolia, Japan. With these paradigm shifts in Indian foreign policy discourse in mind, this study will try to uncover the following objectives

1. To find out the major changes and challenges taking place in India's North-East Asian Policy and

2. To explore India's possibilities and potentials of economic and energy cooperation with Mongolia and how this relation can assist India to counterbalance China's hegemonic position in the region.

The crucial element of any research activity is to systematically and scientifically uncover the pertinent issues of foreign relations by comprehending the trajectory and changes happening in the link. These activities necessitate a complete understanding of the sources available to understand both the theoretical and practical feasibility of conducting the study. This study will try to understand India's potentials in North-Eastern Asia utilizing empirical data, but the analysis will remain qualitative (Creswell \& Poth, 2016). Existing literature, both primary and secondary sources, e-resources, and news articles on this topic above are used extensively. Existing data will be collected into parts of specific themes that researchers have prepared and analyzed using Miles and Huberman's analytical techniques (2003). 
Khazanah Sosial, Vol. 3 No. 3: 138-146

Unlocking India's potentials in Far East Asian Region: Rethinking Indo-Mongolia ties in the present context

Subhash Kumar and Souvik Chatterjee

\section{RESULT AND DISCUSSION}

\section{Result}

\section{India's Act East and Look North Policy: Connecting Central, North East Asia and Beyond}

The Focus of Indian's Act East Policy which is nothing but an extension of India's Look East Policy launched under former PM PV Narashima Rao during the 1990s, brings systematic changes in Indian Foreign Policy discourse (Mohan, 2015). The significant aspects of this act are strengthening economic and trade activities with Southeastern neighboring countries and restricting the ever-increasing presence of China in the region (Blah, 2018). Despite the multilateral engagement outlined and promised under India's Look East Policy, the major focus was guided by economic interests. But with the heralding of India's Act East Policy unveiled in the $12^{\text {th }}$ ASEAN-India summit in 2014, India's emphasized improving economic cooperation, but this act opened up new avenues for Political, Security, and Energy cooperation. Under this Act, India and Southeast Asian countries are eager to co-operate in Counter-Terrorism, Cyber Security Coordination, Capacity building measures, and Maritime Cooperation using forums such as the Expanded ASEAN Maritime Forum.

Though India's Act East Policy was mainly framed keeping in the focus of India's Southeast Asian neighbors and to counter Chinese hegemony in the region by augmenting economic, trade cooperation, it would be wrong to assume that Act East Policy in the current phrase is only limited to Southeast Asian Region. Rather Indian government supplements India's Act East Policy by articulating India's Look North Policy, which focuses on connecting Central Asia and the far East Asian region. Despite India's deep historical, cultural, and religious linkages with the Central Asia region, India's contracts with the Central Asian States deteriorated with the collapse of the USSR and with India moving towards neo-liberal ideology. But over the last decade, Central Asia occupies a key position due to the ongoing power tussles regarding energy resources (Ahmed, 2012). India is also aware of its geopolitical and significance in energy security. As a result, India officially unveiled Connect Central Asia Policy at the first meeting of the IndiaCentral Asia Dialogue in 2012. This act goes beyond the objectives of Look East Policy by encompassing multilateral and holistic engagement ranging from Economic, Energy Cooperation to Political, Infrastructural, and Technological Cooperation. To counter the Chinese Policy of Strategic encirclement, India focuses on developing relations stretches from the South East Asian region to Central Asia and Far East Asia under the ambit of Act East Policy and India's Look North Policy.

At the same time, India, to extend its sphere of influence in Far East Asia, unveiled Act Far East Policy under the leadership of PM Narendra Modi at the $5^{\text {th }}$ Eastern Economic Forum held in Vladivostok and provided a $\$ 1$ billion line of credit for the development of Far East Asian region. The Major focus of this policy is to expand trade and explore energy resources jointly by Russia and India in Russian Far Eastern Areas. Similarly, both Russia and India partner to increase investment, cooperation in oil, gas mining, nuclear energy, and increasing maritime connectivity. At the same forum, PM Modi held talks with Mongolian and Japanese Counterparts. Modi, in his speech, highlighted India's aim and objectives in the region. He said India is looking forward to boosting cooperation with Russia's Far East and India, seeking stronger healthcare, education, skill development, and many other sectors. Being aware of Mongolia's geopolitical significance as a buffer State between China and Russia, New Delhi focuses on maintaining cordial relations with Ulaanbaatar. At the same time, India's policy makers are well aware that India's success or failure in the region essentially depends upon Mongolia, a gateway to North-East Asia. India, in 
Khazanah Sosial, Vol. 3 No. 3: 138-146

Unlocking India's potentials in Far East Asian Region: Rethinking Indo-Mongolia ties in the present context

Subhash Kumar and Souvik Chatterjee

this regard, is focused on utilizing various institutional setups like Shanghai Co-operation to foster IndoMongolia relations.

\section{Chinese Factor in India's North-East Asian Policy}

Regardless of India's growing interest in the region, both policy-wise and diplomatically, China plays a key role in the region (Sigdel, 2020). Chinese supremacy in trade, commerce, and other areas demonstrates China's hegemonic status in the region. Similarly, China, Russia, Japan, Mongolia, the People's Republic of Korea, and the People's Republic of China make up the North-East Asian region. The People's Republic of Korea is one of the world's fastest-growing economies, and China has long been the region's most significant trading partner. In 2018, the entire trade volume between China and other North Eastern countries exceeded 758 billion U.S. dollars, demonstrating China's dominance in the region (Xia, 2019).

Similarly, both China and Japan, the region's two giants, are cognizant of the region's energy potential and are investing extensively in the energy sector (Bedeski \& Swanström, 2012). Mongolia's major aid contributor is Japan, and Mongolia's most significant economic partner is the People's Republic of China. As a result, despite the growing political unrest in the region, particularly between North and South Korea, China can conduct business as usual. At the same time, China is inviting all North-East Asian countries to participate in a multilateral dialogue to coordinate and develop regional energy, trade, and infrastructure development strategies and policies. As a result, it's only natural that countries like Mongolia and North Korea, which lack technological superiority and have one of the region's weakest economies, are occasionally influenced by Chinese policy. In contrast, despite India and Mongolia having long had historical and cultural ties, India's political, economic, and energy relations with Mongolia are essentially limited (Lepekhov, 2017). Despite Mongolia's expanding contacts with Western countries, its international and internal policies are still heavily influenced by its immediate neighbors, particularly China.

The potential for bilateral trade between India and Mongolia was estimated at $\$ 8.45$ billion in 2015, but actual bilateral trade between the two countries was just $\$ 12.03$ million (De \& Pan, 2017, p.38). Apart from its geopolitical importance, Mongolia is rich in natural resources and minerals but lacks the technology to assess and harvest them; India can help here. Mongolia plays a significant role in India's Act East Policy and links Asia's far eastern regions. Although India is always threatened by Chinese hegemony in South Asia, it has been unable to spread its influence beyond its near neighbors. Mongolia also has a significant influence on northeastern regional cooperation.

\section{Mongolia's Importance in Indian Foreign Policy Discourse is Increasing}

The critical question now is why Mongolia has suddenly become so significant to India and the rest of the world. Mongolia's geopolitical and strategic consequences are mentioned in most classic foreign policy textbooks. However, there are other causes that intrigue India and the rest of the globe in Mongolia, in addition to geopolitical positions. These topics span from energy and economic Cooperation to Mongolia's liberalization and transition to democracy to China's growing aggressiveness in northeast Asia.

Economic and Energy Co-operation: Heavy machinery and natural oil products were imported from the Soviet Union starting in the 1920s (Mishra, 2019; Nyamdavaa, 2003). Mongolia's economy was primarily agricultural during the time, with incremental technical transformations based on communist philosophy. Mongolia was pushed to embrace rapid industrialization and modernization while 
Khazanah Sosial, Vol. 3 No. 3: 138-146

Unlocking India's potentials in Far East Asian Region: Rethinking Indo-Mongolia ties in the present context

Subhash Kumar and Souvik Chatterjee

maintaining its agricultural growth by joining the Council for Mutual Assistance during the Cold War. Mongolia has pursued multi-pillar diplomacy and the Third Neighbors Policy since the end of the Cold War, allowing India to meet its energy needs. Mongolia has abundant natural resources that have yet to be properly explored and exploited due to a lack of infrastructure. Oil, gold, silver, iron, coal, copper, molybdenum, tungsten, phosphates, tin, nickel, zinc, and fluorspar are among Mongolia's vast natural resources. As a result, mining has become a significant source of national wealth, contributing to a significant increase in GDP of 13.43 billion dollars (Thomas, 2012). In Mongolia, the Indian government has already invested in several geostrategic projects. From 2006 onwards, the Nomadic Elephant joint military exercise between India and Mongolia has strengthened the relationship between the Indian and Mongolian Armed Forces. Mongolia received a \$1 billion line of credit from India in 2015 to build its first oil refinery, which a high-level visit by Smt followed. Sushma Swaraj. Mongolian President Khaltmaagiin Battulga visited India after PM Modi's historic visit to Mongolia in 2015 to discuss trade and investment opportunities in the Mongolian energy sector. The 7th Virtual Meeting between India and Mongolia took place recently. India praised Mongolia's decision to join the International Solar Alliance (ISA) and emphasized the importance of further cooperation between the two countries in promoting the use of clean energy (Tripathi, 2020). Union Minister of Petroleum and Natural Gas and Steel Dharmendra Pradhan participated in a virtual review meeting between India and Mongolia, Mr. L. Oyun-Erdene, a Mongolian equivalent, was contacted. Greater cooperation in the hydrocarbons and steel sectors was emphasized, and Pradhan thanked Mongolian leaders for their prompt approvals of the pending greenfield Mongol Refinery Project, which is being built under a Line of Credit from the Indian government and is expected to be completed by 2022 (Mehrotra et al., 2013).

However, despite India's increased interest in Mongolia from a policy and diplomatic standpoint, China holds a crucial position in the region. Chinese supremacy in the trade, commerce, and energy sectors demonstrates China's hegemony in the Northeast Asian region. Similarly, China and other heavyweights are aware of Mongolia's energy potential and significantly invest in the energy sector (Eder, 2013). Mongolia's major aid provider is Japan, whereas Mongolia's largest economic partner is the People's Republic of China. At the same time, China is encouraging all North-East Asian countries to participate in a multilateral dialogue to coordinate and build regional energy, commerce, and infrastructure development strategies and policies. As a result, it's only natural that countries like Mongolia and North Korea, which lack technological superiority and have one of the region's weakest economies, are occasionally influenced by Chinese policy. On the other side, although India and Mongolia have long had historical and cultural ties, India's involvement with Mongolia in the energy sector has been overlooked for far too long. Its close surroundings, particularly China, heavily influence Mongolia's energy policy. Apart from its geopolitical importance, Mongolia is rich in natural resources and minerals but lacks the technology to assess and harvest them; India can help here. Mongolia plays a significant role in India's Act East Policy and in connecting Asia's further east. While India is in constant threat of Chinese hegemony in the South Asia region, India could not expand its influence beyond its immediate neighbors. Mongolia also has a significant influence on northeastern regional cooperation.

\section{Discussion}

\section{India's Engagement With Mongolia via Shanghai Cooperation Organization}

Mongolia was granted observer status by the Shanghai Cooperation Organization in 2014, increasing Mongolia's opportunities and chances for expanding its ties beyond its close neighbors. Despite 
Khazanah Sosial, Vol. 3 No. 3: 138-146

Unlocking India's potentials in Far East Asian Region: Rethinking Indo-Mongolia ties in the present context

Subhash Kumar and Souvik Chatterjee

Mongolia's move to a market economy and adopting a democratic government, its foreign policy has always been influenced by its close ties to China and Russia. However, as Anthony Rinna observed, the main reason for Mongolia's choice to join the SCO is more or less driven by security concerns. Mongolia's decision to join the SCO could be interpreted as an attempt to put its foreign policy ambitions into practice. Mongolia pursued a multi-pillared foreign policy after 1990 to forge close ties with the world's major players while also intending to play a catalytic role in regional and global forums. (Krishna, 2014). SCO's distinctiveness stems in the fact that it offers Mongolia with the institutional framework through which it can sufficiently and autonomously pursue its international engagement goals without aligning to a particular pole, notwithstanding Mongolia's involvement in many regional and global forums (namely Russia or China) (Rinna, 2014). On the other side, the SCO plays a critical role in implementing India's Connect Central Asia Policy. India is committed to using the SCO to improve regional commerce, commercial prospects, and connectivity. However, China's Belt Road Initiative is India's largest challenge in terms of boosting regional connectivity. All SCO members except India backed this plan at the SCO Foreign Ministers meeting, which impedes India's aims while reinforcing China's dominant position in the region and in the forum. There are numerous opportunities for India to benefit from this platform. India is anticipated to use the SCO to promote counter-terrorism cooperation and a variety of other securityrelated problems. India, on the other hand, as one of the world's top energy consumers, anticipates expanded access to Central Asian oil and gas exploration projects. Despite India's diplomatic win in gaining full membership in the Chinese-dominated SCO, Pakistan's full participation and China's overbearing influence in the forum conceal India's objectives. India is now attempting to counter this by forging closer ties with Mongolia, a member of the forum as an observer. Mongolia is also searching for an alternate market for its energy resources, as it has been reliant on Russia for a long time and is keen to investigate the SCO forum in this regard. Mongolia's leadership attempts to use the Shanghai Cooperation Organization (SCO) to expand Mongolia's interests beyond Northeast Asia by connecting Central Asia and South Asia (Li, 2016). Being the largest and most powerful country in South Asia, India is likely to play a significant role. Mongolia intends to use the SCO to strengthen ties with nations such as India, leveraging its infrastructure and technological advantages to promote Ulaanbaatar's mineral and energy resources in the South Asian region.

\section{Analysis of India's potential in the East Asia Region and its relationship with Mongolia}

In contemporary times, it is undeniable that Modern Mongolia occupies a central position in Indian foreign policy discourse from a geostrategic point of view and economic and energy avenues opening up in the region. Mongolia's strategic position at the cross juncture between Central Asia, North East Asia, Far East Asia generally attracts countries like India (Stobdan, 2015). Mongolia's geographical closeness with Afghanistan on one side and China on the other side reinforce Mongolia's importance. Despite the geophysical barrier that obscures India's direct engagement with Mongolia, India's greatest asset is India's cultural power. From time to time Indian government, especially NDA, emphasized India's old age historical ties through Buddhism and India's active role in promoting democracy. India is also looking to import rich minerals and uranium from Mongolia, while India is expected to build an infrastructural setup in Mongolia. India's active role in the non-align movement, the reputation of being the largest democracy, and the principle of non-intervention greatly attract Mongolia's foreign policymakers.

Similarly, there is a growing anti -Chinese feeling developing in Mongolia due to its long history of suppressing and opposing residents of Inner Mongolia. At the same time, Mongolia, through its third 


\section{Khazanah Sosial, Vol. 3 No. 3: 138-146}

Unlocking India's potentials in Far East Asian Region: Rethinking Indo-Mongolia ties in the present context

Subhash Kumar and Souvik Chatterjee

neighbor approach, tries to pursue an independent foreign policy without aligning with either Russia or China. But despite India's growing fondness for Mongolia, both economically and diplomatically, China occupies a central position in Mongolian foreign policy discourse. Before Mongolia's transformation to democracy, its foreign, as well as a domestic policy, was guided and molded by USSR. Still, in recent times, China's influence in the region is so intense and far-reaching that many people fear losing Mongolia's autonomy to China once again (Stobdan, 2015).

\section{CONCLUSION}

India recognizes the importance of Mongolia as a geographical axis and an open economic incentive in the region. Mongolia is expected to play an influential role in increasing India's influence in Northeast Asia. At the same time, both Mongolia and India are partnering with each other such as engaging in defense and strategic ties, policymaking to strengthen their partnership. But the success or failure of India's approach in Northeast Asia will essentially depend on India's political and diplomatic will that how well Indian policymakers can turn India's interest in regional integration into reality. In this regard, civil society, media, and Indian cultural influences in the region are expected to play an influential role in articulating a positive image of India in the general public's mindset and thereby helping India occupy an important position in Mongolia's foreign and security policy.

\section{REFERENCES}

Ahmed, A. (2012). The Strengthening Sino-Pakistani Nexus As a Major Strategic Challenge for India. INDO-PAK TENSION Solution for Conflict or Cooperation, 3(5), 313.

Bedeski, R. E., \& Swanström, N. (2012). Eurasia's ascent in energy and geopolitics: Rivalry or partnership for China, Russia and Central Asia? Routledge.

Blah, M. (2018). China's belt and road initiative and India's concerns. Strategic Analysis, 42(4), 313332.

Chandramohan, B. (2015). India and Mongolia: Uranium and Beyond. Strategic Analysis Paper. Future Directions International, 19.

Creswell, J. W., \& Poth, C. N. (2016). Qualitative inquiry and research design: Choosing among five approaches. Sage publications.

D'Evelyn, C. A. (2013). Music between worlds: Mongol music and ethnicity in Inner Mongolia, China. University of Hawai'i at Manoa.

Eder, T. S. (2013). China-Russia relations in Central Asia: energy policy, Beijing's new assertiveness and 21st century geopolitics. Springer Science \& Business Media.

Ganbat, D. (2012). National Security Concept of Mongolia: Basic Principle. National Security Concept, The Institute for Strategic Studies, Ulaanbaatar.

Huang, K., Lee, F., \& Lin, T. (2013). Partisanship and institutional trust: A comparative analysis of emerging democracies in East Asia. Taiwan Journal of Democracy, 9(1), 47-71.

Krishna, V. (2014). Mongolian Foreign Policy Implications for Russia and China. Mongolian Journal of International Affairs, 19, 67-81.

Lepekhov, S. (2017). Historical and cultural role of Indian Mitra and Maitreya cults in the uniting process of Eurasia. In Eurasia and India (pp. 13-20). Routledge.

Li, M. (2016). From look-West to act-West: Xinjiang's role in China-Central Asian relations. Journal of Contemporary China, 25(100), 515-528.

Mehrotra, S., Gandhi, A., \& Sahoo, B. K. (2013). Estimating India's Skill Gap: on a Realistic Basis for 2022. Economic and Political Weekly, 102-111.

Miles, M. B., \& Huberman, A. M. (2003). Analyse des données qualitatives. De Boeck Supérieur. 
Khazanah Sosial, Vol. 3 No. 3: 138-146

Unlocking India's potentials in Far East Asian Region: Rethinking Indo-Mongolia ties in the present context

Subhash Kumar and Souvik Chatterjee

Mishra, S. (2019). Reassessing Mongolia-India Economic Relationship: Present, Past and Future. GIS Business, 14(6), 1156-1167.

Mohajan, H. K. (2017). Two criteria for good measurements in research: Validity and reliability. Annals of Spiru Haret University. Economic Series, 17(4), 59-82.

Mohan, C. R. (2015). Foreign Policy after 1990. In The Oxford Handbook of Indian Foreign Policy. OUP Oxford.

Mote, V. L. (2018). Siberia: worlds apart. Routledge.

Nyamdavaa, 0. (2003). Mongolia-India Relations. Pentagon Press.

Prawdin, M. (2017). The Mongol Empire: Its Rise and Legacy. Routledge.

Rinna, A. V. (2014). The Shanghai Cooperation Organisation and Mongolia's Quest for Security. Indian Journal of Asian Affairs, 63-80.

Sigdel, A. (2020). India in the Era of China's Belt and Road Initiative: How Modi Responds to Xi. Lexington Books.

Soni, S. K. (2016). Emerging Dimensions of India-Mongolia Relations. Indian Foreign Affairs Journal, 11(1), 51.

Stobdan, P. (2015). India and Mongolia: Modi on Ashoka's Path. Institute for Defence Studies and Analyses. https://idsa.in/idsacomments/IndiaandMongolia_pstobdan_130515.

$\begin{array}{llll}\text { Thomas, G. } & \text { P. } & \text { (2012). AZO Mining. Www.Azomining.Com. }\end{array}$ https://www.azomining.com/Article.aspx?ArticleID=106

Tripathi, S. (2020). India, Mongolia held 7th meeting of joint committee on cooperation to focus on bilateral ties. JagranJosh. https://www.jagranjosh.com/current-affairs/india-mongoliaheld-7th-meeting-of-joint-committee-on-cooperation-to-focus-on-bilateral-ties1607081958-1

Tsokhas, K. (2013). Poverty, inequality, and inclusive growth in Asia: Measurement, policy issues, and country studies. Taylor \& Francis.

Warsah, I., Masduki, Y., Imron, Daheri, M., \& Morganna, R. (2019). Muslim Minority in Yogyakarta: Between Social Relationship and Religious Motivation. Qudus International Journal of Islamic Studies, 7(2), 367-398. https://doi.org/10.21043/qijis.v7i2.6873

Xia, L. (2019). China Focus: Northeast Asian countries eye closer ties to boost global economy. Xinhuanet. http://www.xinhuanet.com/english/2019-08/27/c_138342481.htm

Zhang, J. (2012). Buddhist Diplomacy: History and status quo. CPD Perspective, 7.

Zhang, X., \& Zhang, S. (2017). China-Mongolia-Russia economic corridor and environmental protection cooperation. R-Economy, 3(3), 161-166. 